\title{
ZNACZENIE RELACJI TERAPEUTYCZNEJ W PROCESIE TERAPII PACJENTÓW PO TRANSPLANTACJI NERKI
}

\section{THE IMPORTANCE OF THERAPEUTIC RELATIONSHIPS IN THERAPY OF PATIENTS AFTER KIDNEY TRANSPLANTATION}

\author{
Joanna Owsianowska ${ }^{1, a}$, Natalia Pyster ${ }^{2}$, Renata Robaszkiewicz-Bouakaz ${ }^{1, b}$, Anna Kędzierska ${ }^{1, c}$, \\ Dorota Branecka-Woźniak ${ }^{3, d}$, Sylwia Wieder-Huszla ${ }^{1, e}$ \\ ${ }^{1}$ Zakład Pielęgniarstwa Specjalistycznego, Wydział Nauk o Zdrowiu, Pomorski Uniwersytet Medyczny w Szczecinie \\ ${ }^{2}$ Studenckie Koło Naukowe, Zakład Pielęgniarstwa Specjalistycznego, Wydział Nauk o Zdrowiu, Pomorski Uniwersytet Medyczny w Szczecinie \\ ${ }^{3}$ Katedra i Zakład Ginekologii i Zdrowia Prokreacyjnego, Wydział Nauk o Zdrowiu, Pomorski Uniwersytet Medyczny w Szczecinie
}

${ }^{a}$ https://orcid.org/0000-0001-9096-8477

${ }^{\mathrm{b}}$ https://orcid.org/0000-0003-1674-0903

${ }^{\mathrm{c}}$ https://orcid.org/0000-0002-5772-2536

${ }^{\mathrm{d}}$ https://orcid.org/0000-0001-7561-1509

${ }^{\text {e }} \mathrm{https} / / /$ orcid.org/0000-0002-6084-5780

DOI: https://doi.org/10.20883/pielpol.2020.2

\section{STRESZCZENIE}

Wstęp. Przewlekła choroba nerek stanowi złożony zespół chorobowy, który charakteryzuje się osłabieniem funkcji nerek. Najskuteczniejszą metodę leczenia nerkozastępczego stanowi transplantacja nerki, która przedłuża życie chorych. Zabieg ten wywołuje jednak szereg emocji, zarówno pozytywnych, jak i negatywnych. Nawiązanie relacji terapeutycznej z chorym stanowi podstawę w procesie leczenia.

Cel. Celem pracy było przedstawienie znaczenia relacji terapeutycznej pielęgniarka - pacjent w procesie terapii po transplantacji nerki.

Materiał i metody. Badania były wprowadzone metodą sondażu diagnostycznego od grudnia 2017 r. do marca 2018 r. Grupę badaną stanowiło 121 pacjentów (59 kobiet, 62 mężczyzn) Kliniki Nefrologii, Transplantologii i Chorób Wewnętrznych SPSKS nr 2 oraz Oddziału Nefrologii i Transplantacji Nerek Samodzielnego Publicznego Wojewódzkiego Szpitala Zespolonego w Szczecinie. Do badań zastosowano autorski kwestionariusz ankiety składający się z 25 pytań zamkniętych.

Wyniki. Większość ankietowanych oceniła udzielane przez pielęgniarki informacje dotyczące zasad i zachowań obowiązujących w oddziale na poziomie dobrym i bardzo dobrym. Zdaniem 87,6\% badanych relacja $z$ personelem pielęgniarskim daje poczucie bezpieczeństwa, a u 75,8\% respondentów wpłynęła na obniżenie lęku. Zdecydowana większość badanych deklarowała, że dzięki relacji interpersonalnej z pielęgniarką nastąpił u nich wzrost wiedzy związanej z chorobą.

Wnioski. 1) Badana grupa pacjentów wysoko oceniała znaczenie relacji terapeutycznej z personelem pielęgniarskim. 2) Wiek, płeć, wykształcenie, a także czas, który upłynął od przeszczepienia nerki i zdiagnozowania choroby, wpływały na poziom zadowolenia z relacji terapeutycznej z personelem pielęgniarskim. 3) Wsparcie informacyjne personelu pielęgniarskiego wywiera istotny wpływ na poczucie bezpieczeństwa i obniżenie lęku pacjentów po transplantacji nerki w trakcie hospitalizacji.

SŁOWA KLUCZOWE: przeszczepienie nerki, pacjent, pielęgniarka, relacja terapeutyczna.

\section{ABSTRACT}

Introduction. Chronic renal disease is a complex disease, characterized by reduced kidney function. The most effective method of renal replacement treatment is kidney transplantation, which prolongs patients' lives. This procedure, however, evokes a lot of positive and negative emotions. Developing a therapeutic relationship with the patient is a basis in the therapeutic process.

Aim. The purpose of this study was to present the importance of the nurse-patient therapeutic relationship in therapy following kidney transplantation.

Material and methods. This survey-based study was conducted from December 2017 to March 2018. The study sample contained 121 patients (59 women, 62 men) of the Clinic of Nephrology, Transplantology, and Internal Diseases, Independent Public Clinical Hospital no. 2, and the Ward of Nephrology and Kidney Transplantation, Independent Public Voivodeship Integrated Hospital in Szczecin. The research instrument employed in the study was a self -developed questionnaire including 25 closed-ended questions.

Results. The majority of the surveyed assessed information provided by nurses on the rules of conduct binding in the ward as good and very good. $87.6 \%$ of the respondents claimed that the relationship with nurses gave a sense of safety, and $75.8 \%$ that it had reduced their fear. A vast majority of the respondents asserted that interpersonal relationships with nurses had improved their knowledge of disease.

Conclusions. 1) The patients highly valued therapeutic relationships with nursing staff. 2) Age, sex, education, as well as the time from kidney transplantation and a diagnosis of the disease had an effect on the patients' satisfaction with therapeutic relationships with nursing staff. 3) Information provided by nursing staff has a substantial impact on the feeling of safety and the reduction of fear in patients after kidney transplantation during hospitalization.

KEYWORDS: kidney transplantation, patient, nurse, therapeutic relationships. 


\section{Wprowadzenie}

Przewlekła choroba nerek (PCHN) stanowi złożony zespół chorobowy, charakteryzujący się powolnym, ale nieodwracalnym i najczęściej postępującym osłabieniem funkcji nerek. Pogorszenie czynności nerek spowodowane jest zmniejszoną liczbą czynnych nefronów, co powoduje pogorszenie funkcji wydalniczej narządu [1-2]. Obraz kliniczny PCHN uzależniony jest od stopnia zaawansowania schorzenia. Początkowo choroba może przebiegać bezobjawowo lub symptomy mogą nie być charakterystyczne dla przewlekłej choroby nerek. Dopiero wraz ze spadkiem współczynnika przesączania kłębuszkowego (GFR) zaczynają pojawiać się objawy, a także powikłania ze strony narządów i układów, a częstość ich występowania zależy od stopnia zaawansowania choroby [3-4]. Dostępne dane epidemiologiczne wskazują na wzrost liczby osób chorych na PCHN [5].

Transplantacja nerki stanowi najlepszą metodę leczenia nerkozastępczego, ponieważ poprawia jakość i przedłuża życie chorego [6]. Może być wykonywana zarówno u pacjentów dializowanych, jak i u chorych przed rozpoczęciem dializoterapii. Przeszczepiana nerka może pochodzić od dawcy zmarłego lub żywego, a podstawowym warunkiem jest zgodność głównych grup krwi oraz ujemny wynik próby krzyżowej pomiędzy surowicą biorcy i limfocytami dawcy. Próba krzyżowa wyklucza u biorcy obecność przeciwciał limfocytotoksycznych skierowanych przeciwko antygenom dawcy [2, 4].

W okresie potransplantacyjnym występuje szereg problemów, które mogą wywierać negatywny wpływ na adaptację pacjenta do nowej sytuacji życiowej. Ograniczenia oraz zasady, które obowiązują po przeszczepieniu nerki mogą wpływać ujemnie na konieczność aktywnego udziału chorego w procesie terapeutycznym [2, 4, 7]. Stosowanie leczenia immunosupresyjnego, którego celem jest zapobieganie i leczenie odrzucania przeszczepionej nerki sprzyja rozwojowi zakażeń, nowotworów oraz wywołuje szereg działań niepożądanych w narządach [8]. Kontakt z pacjentem jest zjawiskiem złożonym, wymagającym od personelu medycznego nie tylko wiedzy medycznej, ale także, a może przede wszystkim, umiejętności nawiązywania relacji terapeutycznej. Efektywna, empatyczna komunikacja dostarcza wsparcia, obniża napięcie emocjonalne i poziom stresu u chorych. Przyczynia się również do poznania potrzeb pacjenta, oszacowania oceny zapotrzebowania na wsparcie informacyjne o zasadach i zachowaniach, których należy przestrzegać oraz ułatwia szybkie i wczesne zdiagnozowanie pierwszych objawów lękowych lub depresyjnych [9-12]. Zadaniem pielęgniarki jest zatem nie tylko zadbanie o zdrowie fizyczne pacjenta: dokonywanie pomiarów parametrów życiowych, regularne podawanie leków czy aktywność fizyczna, ale przede wszystkim zapewnienie poczucia bezpieczeństwa, edukowanie i wspieranie [13-14]. Obecnie uważa się, że relacja terapeutyczna z pacjentem po transplantacji nerki nie stanowi tylko dodatku do procesu leczenia, ale jest podstawą profesjonalnej opieki [15].

\section{Cel pracy}

Celem pracy było przedstawienie znaczenia relacji terapeutycznej pielęgniarka - pacjent w procesie terapii po transplantacji nerki.

\section{Materiał}

Grupę badaną stanowiło 121 pacjentów (59 kobiet i 62 mężczyzn) po przeszczepieniu nerki, hospitalizowanych w Samodzielnym Publicznym Szpitalu Klinicznym Nr 2 w Klinice Nefrologii, Transplantologii i Chorób Wewnętrznych oraz w Samodzielnym Publicznym Wojewódzkim Szpitalu Zespolonym na Oddziale Nefrologii i Transplantologii Nerek w Szczecinie. Najliczniejszą grupę badanych $24,8 \%$ stanowiły osoby w wieku 60 i więcej lat. Respondenci, których wiek zawierał się w przedziale 40-49 lat stanowili $22,3 \%$ badanych, natomiast $20,7 \%$ osób miało poniżej 30 lat. Osoby między 50. a 59. rokiem życia stanowiły $17,4 \%$ badanej grupy. Największy odsetek badanych - 40,5\% - stanowiły osoby, u których chorobe zdiagnozowano ponad 5 lat temu. Równie wysoki odsetek - 38,8\% - stanowili respondenci, u których diagnoza została postawiona 5 lat temu lub mniej. Najmniej liczną grupe - 20,7\% - reprezentowali pacjenci z chorobą zdiagnozowaną mniej niż 1 rok temu. Najliczniejsza grupa badanych - 53,7\% - miała przeprowadzoną transplantację nerki mniej niż rok temu. 5 lat temu lub mniej zabieg przeszczepienia był wykonany u 28,1\% respondentów. Tylko u 18,2\% pacjentów transplantacja była wykonana ponad 5 lat temu. Rozkład wykształcenia w badanej grupie przedstawiał się w sposób następujący: 34,7\% ankietowanych deklarowało wykształcenie średnie, 28,9\% - zasadnicze zawodowe, 27,3\% - wykształcenie wyższe i 7,4\% - podstawowe. Tylko 1,7\% badanej grupy deklarowało wykształcenie gimnazjalne. Badania nie wymagały zgody Komisji Bioetycznej PUM. Zdecydowaną większość badanych (104 osoby) stanowiły osoby po pierwszej transplantacji, po kolejnym przeszczepieniu było 17 chorych.

\section{Metody}

Badania były prowadzone metodą sondażu diagnostycznego od grudnia 2017 do marca 2018 r. w oparciu o wykorzystanie autorskiego kwestionariusza 
ankiety, który składał się z 25 pytań zamkniętych, dotyczących sytuacji socjodemograficznej, zdrowotnej i znaczenia relacji terapeutycznej w procesie terapii. Analize statystyczną zebranego materiału wykonano w programie SPSS Statistica 24.0. Zależności pomiędzy wybranymi zmiennymi zbadano z zastosowaniem testu niezależności chi-kwadrat. Jako istotne przyjęto efekty dla których wartość prawdopodobieństwa p była mniejsza od $0,05(p<0,05)$.

\section{Wyniki}

Prawie połowa, tj. 42,5\%, badanych pacjentów uznała, że sposób udzielania przez pielęgniarki informacji dotyczących zasad obowiązujących w oddziale, zachowań związanych z chorobą i/lub przeszczepieniem nerki, wykonywaniem zabiegów pielęgnacyjnych był na bardzo dobrym poziomie. Stosunkowo liczna grupa badanych - 40\% - określiła go na poziomie dobrym, natomiast $12,5 \%$ ankietowanych uważało, że pielęgniarki udzielają informacji na poziomie przeciętnym. Nieliczna grupa badanych negatywnie oceniła udzielane wsparcie informacyjne (Rycina 1).

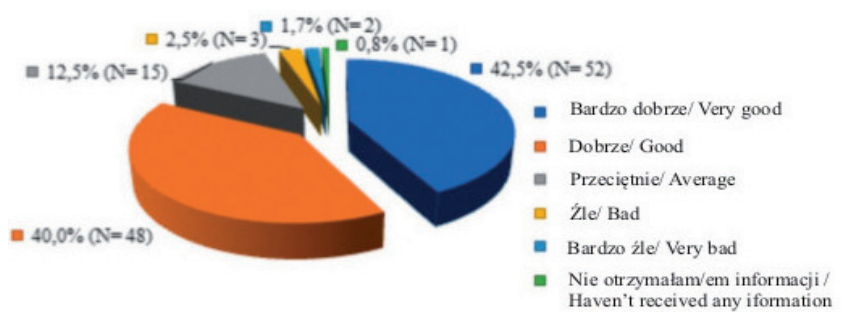

Rycina 1. Analiza poziomu udzielanych informacji dotyczących zachowań i zasad obowiązujących w oddziale

Figure 1. Analysis of the quality of information on the rules of conduct binding in the ward

Źródło: opracowanie własne

Source: author's own analysis

Analiza wykazała istotne statystycznie zależności pomiędzy płcią i czasem od przeszczepienia nerki, a wpływem wsparcia informacyjnego udzielanego przez pielęgniarki na poczucie bezpieczeństwa ankietowanych. Wyższe poczucie bezpieczeństwa dzięki udzielanemu przez pielęgniarki wsparciu informacyjnemu wykazano u kobiet i osób, u których od przeszczepienia minęło ponad 5 lat. Nie wykazano istotnych statystycznie zależności pomiędzy wiekiem, wykształceniem, czasem od zdiagnozowania choroby a wpływem wsparcia informacyjnego na poczucie bezpieczeństwa (Tabela 1).
Zdecydowana większość ankietowanych, tj. 81,7\%, uznała, że informacje udzielane przez pielęgniarki wpłynęły pozytywnie na poziom ich wiedzy w zakresie zachowań związanych z chorobą i/lub przeszczepem nerki. Tylko $10 \%$ badanych uważało, że informacje te nie pogłębiły ich wiedzy w tym zakresie, zaś $8,3 \%$ nie potrafiło określić swojego zdania (Rycina 2).

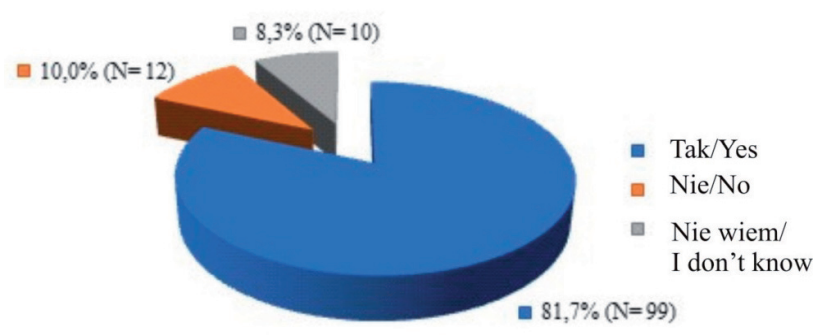

Rycina 2. Ocena wpływu informacji udzielanych przez pielęgniarki na poziom wiedzy badanych w zakresie zachowań związanych z chorobą i/lub przeszczepem

Figure 2. The impact of information provided by nurses on the level of the patients' knowledge concerning the behavior associated with the disease and/or kidney transplantation

Źródło: opracowanie własne

Source: author's own analysis

Przeprowadzona analiza wykazała istotne statystycznie zależności pomiędzy wykształceniem a wpływem relacji terapeutycznej na poprawę samopoczucia ankietowanych w trakcie hospitalizacji. Osoby z wykształceniem gimnazjalnym, zawodowym i średnim odczuwały większy wpływ relacji terapeutycznej pacjent-pielęgniarka na poprawę samopoczucia niż osoby z wykształceniem wyższym i podstawowym. Nie wykazano istotnych statystycznie zależności pomiędzy płcią, wiekiem, czasem od zdiagnozowania choroby oraz czasem od transplantacji nerki, a wpływem relacji terapeutycznej pacjent/pielęgniarka na poprawę samopoczucia (Tabela 2).

Analiza wykazała istotne statystycznie zależności pomiędzy płcią i czasem od zdiagnozowania choroby, a wpływem relacji terapeutycznej pacjent/pielęgniarka na obniżenie lęku w trakcie hospitalizacji. Z przeprowadzonej analizy wynika, że kobiety oraz osoby, u których upłynęło powyżej 5 lat od zdiagnozowania choroby odczuwały większy wpływ relacji terapeutycznej z pielęgniarkami na obniżenie lęku niż mężczyźni i respondenci, u których chorobę zdiagnozowano mniej niż rok temu. Nie wykazano istotnych statystycznie zależności pomiędzy wiekiem, wykształceniem, czasem minionym od transplantacji nerki a wpływem relacji terapeutycznej pacjent-pielęgniarka na obniżenie lęku (Tabela 3). 
Tabela 1. Wpływ wsparcia informacyjnego udzielanego przez pielęgniarki na poczucie bezpieczeństwa pacjentów Table 1. The impact of information support provided by nurses on the patients' sense of safety

\begin{tabular}{|c|c|c|c|c|c|c|c|}
\hline & & \multicolumn{3}{|c|}{$\begin{array}{l}\text { Wsparcie informacyjne udzielane przez pielęgniarki } \\
\text { a poczucie bezpieczeństwa/ } \\
\text { Information support provided by nurses and } \\
\text { a sense of safety }\end{array}$} & \multicolumn{3}{|c|}{$\begin{array}{c}\text { Statystyki testu } \\
\text { chi-kwadrat/ } \\
\text { Chi-square test statistics }\end{array}$} \\
\hline & & Tak/Yes & Nie/No & $\begin{array}{l}\text { Nie wiem/ } \\
\text { Idon't know }\end{array}$ & $\chi^{2}$ & df & $\mathrm{p}$ \\
\hline \multirow[t]{2}{*}{ Płeć/Sex } & Kobieta/Woman & $84,7 \%$ & $6,8 \%$ & $8,5 \%$ & 20,93 & 6 & $0,01^{* *}$ \\
\hline & Mężczyzna/Man & $66,1 \%$ & $16,1 \%$ & $17,7 \%$ & & & \\
\hline \multirow[t]{5}{*}{ Wiek/Age } & Poniżej 30 lat/Below 30 years & $81,0 \%$ & $4,8 \%$ & $14,3 \%$ & 19,13 & 12 & 0,15 \\
\hline & 30-39 lat/years & $76,0 \%$ & $12,0 \%$ & $12,0 \%$ & & & \\
\hline & 40-49 lat/years & $55,6 \%$ & $22,2 \%$ & $22,2 \%$ & & & \\
\hline & 50-59 lat/years & $72,2 \%$ & $16,7 \%$ & $11,1 \%$ & & & \\
\hline & 60 lat i powyżej/years and more & $90,0 \%$ & $3,3 \%$ & $6,7 \%$ & & & \\
\hline \multirow[t]{5}{*}{ Wykształcenie/Education } & Podstawowe/Primary & $55,6 \%$ & $11,1 \%$ & $33,3 \%$ & 13,91 & 15 & 0,53 \\
\hline & Gimnazjalne/Lower secondary & $50,0 \%$ & $0,0 \%$ & $50,0 \%$ & & & \\
\hline & Zasadnicze zawodowe/Vocational & $74,3 \%$ & $14,3 \%$ & $11,4 \%$ & & & \\
\hline & Średnie/Secondary & $78,6 \%$ & $7,1 \%$ & $14,3 \%$ & & & \\
\hline & Wyższe/Tertiary & $78,8 \%$ & $15,2 \%$ & $6,1 \%$ & & & \\
\hline \multirow{3}{*}{$\begin{array}{l}\text { Czas od } \\
\text { diagnozy/The time from } \\
\text { a diagnosis }\end{array}$} & Mniej niż rok temu/Less than one year ago & $76,0 \%$ & $20,0 \%$ & $4,0 \%$ & 8,97 & 9 & 0,44 \\
\hline & 5 lat lub mniej/5 years or less ago & $74,5 \%$ & $12,8 \%$ & $12,8 \%$ & & & \\
\hline & Więcej niż 5 lat/More than 5 years ago & $75,5 \%$ & $6,1 \%$ & $18,4 \%$ & & & \\
\hline \multirow{3}{*}{$\begin{array}{l}\text { Czas od } \\
\text { przeszczepienia/The time from } \\
\text { kidney transplantation }\end{array}$} & Mniej niż rok temu/Less than one year ago & $68,5 \%$ & $25,4 \%$ & $6,2 \%$ & 21,22 & 9 & $0,01^{* *}$ \\
\hline & 5 lat lub mniej/5years or less ago & $64,7 \%$ & $8,8 \%$ & $26,5 \%$ & & & \\
\hline & Więcej niż 5 lat/More than 5 years ago & $81,8 \%$ & $4,5 \%$ & $13,6 \%$ & & & \\
\hline
\end{tabular}

$\chi^{2}$ - test chi-kwadrat/chi-square test, df - liczba stopni swobody/degrees of freedom; $\mathrm{p}$ - poziom istotności//evel of significance " $\mathrm{p}<0,01 \mathrm{p}$ poziom istotności/level of significance

Źródło: opracowanie własne

Source: author's own analysis

Tabela 2. Wpływ relacji terapeutycznej pielęgniarka-pacjent na poprawę samopoczucia pacjentów w trakcie hospitalizacji Table 2. The impact of the nurse-patient therapeutic relationship on the improvement of the patients' well-being during hospitalization

\begin{tabular}{|c|c|c|c|c|c|c|c|}
\hline & & \multicolumn{3}{|c|}{$\begin{array}{l}\text { Relacja terapeutyczna pielęgniarka-pacjent } \\
\text { a poprawa samopoczucia/ } \\
\text { Nurse-patient therapeutic relationship and } \\
\text { the improvement of well-being }\end{array}$} & \multicolumn{3}{|c|}{$\begin{array}{c}\text { Statystyki testu } \\
\text { chi-kwadrat/ } \\
\text { Chi-square test statistics }\end{array}$} \\
\hline & & Tak/Yes & $\mathrm{Nie} / \mathrm{No}$ & $\begin{array}{l}\text { Nie wiem/I } \\
\text { don't know }\end{array}$ & $\chi^{2}$ & $\mathrm{df}$ & $\mathrm{p}$ \\
\hline \multirow[t]{2}{*}{ Płeć/Sex } & Kobieta/Woman & $72,4 \%$ & $13,8 \%$ & $13,8 \%$ & 4,86 & 6 & 0,56 \\
\hline & Mężczyzna/Man & $62,9 \%$ & $16,1 \%$ & $21,0 \%$ & & & \\
\hline \multirow[t]{5}{*}{ Wiek/Age } & Poniżej 30 lat/Below 30 years & $70,0 \%$ & $20,0 \%$ & $10,0 \%$ & 18,03 & 12 & 0,11 \\
\hline & 30-39 lat/years & $68,0 \%$ & $12,0 \%$ & $20,0 \%$ & & & \\
\hline & 40-49 lat/years & $48,1 \%$ & $22,2 \%$ & $29,6 \%$ & & & \\
\hline & 50-59 lat/years & $72,2 \%$ & $22,2 \%$ & $5,6 \%$ & & & \\
\hline & 60 lat i powyżej/60 years and more & $80,0 \%$ & $3,3 \%$ & $16,7 \%$ & & & \\
\hline \multirow[t]{5}{*}{ Wykształcenie/Education } & Podstawowe/Primary & $33,3 \%$ & $22,2 \%$ & $44,4 \%$ & 23,37 & 15 & $0,05^{*}$ \\
\hline & Gimnazjalne/Lower secondary & $100,0 \%$ & $0,0 \%$ & $0,0 \%$ & & & \\
\hline & Zasadnicze zawodowe/Vocational & $74,3 \%$ & $14,3 \%$ & $11,4 \%$ & & & \\
\hline & Średnie/Secondary & $76,2 \%$ & $11,9 \%$ & $11,9 \%$ & & & \\
\hline & Wyższe/Tertiary & $56,3 \%$ & $18,8 \%$ & $25,0 \%$ & & & \\
\hline \multirow{3}{*}{$\begin{array}{l}\text { Czas od } \\
\text { diagnozy/The time from } \\
\text { a diagnosis }\end{array}$} & Mniej niż rok/Less than one year & $62,5 \%$ & $29,2 \%$ & $8,3 \%$ & 14,26 & 9 & 0,11 \\
\hline & 5 lat lub mniej/5 years or less & $66,0 \%$ & $17,0 \%$ & $17,0 \%$ & & & \\
\hline & Więcej niż 5 lat/More than 5 years & $71,4 \%$ & $6,1 \%$ & $22,4 \%$ & & & \\
\hline Czas od & Mniej niż rok/Less than one year & $70,3 \%$ & $15,6 \%$ & $14,1 \%$ & 10,43 & 9 & 0,32 \\
\hline przeszczepienia/ & & & & & & & \\
\hline \multirow{2}{*}{$\begin{array}{l}\text { The time from kidney } \\
\text { transplantation }\end{array}$} & 5 lat lub mniej/ 5 years or less & $55,9 \%$ & $20,6 \%$ & $23,5 \%$ & & & \\
\hline & Więcej niż 5 lat/More than 5 years & $77,3 \%$ & $4,5 \%$ & $18,2 \%$ & & & \\
\hline
\end{tabular}

$\chi^{2}$ - test chi-kwadrat/chi-square test; df - liczba stopni swobody/degrees of freedom; $\mathrm{p}$ - poziom istotności/level of significance $\mathrm{p}<0,05$

Źródło: opracowanie własne

Source: author's own analysis 
Tabela 3. Wpływ relacji terapeutycznej pacjent-pielęgniarka na obniżenie lęku pacjentów w trakcie hospitalizacji Table 3. The impact of the nurse-patient therapeutic relationship on the reduction of the patients' fear during hospitalization

\begin{tabular}{|c|c|c|c|c|c|c|c|}
\hline & & \multicolumn{3}{|c|}{$\begin{array}{l}\text { Relacja pacjent-pielęgniarka a obniżenie lęku w trakcie } \\
\text { hospitalizacji/ } \\
\text { The nurse-patient relationship and the reduction of fear } \\
\text { during hospitalization }\end{array}$} & \multicolumn{3}{|c|}{$\begin{array}{l}\text { Statystyki testu } \\
\text { chi-kwadrat/ } \\
\text { Chi-square test statistics }\end{array}$} \\
\hline & & Tak/Yes & $\mathrm{Nie} / \mathrm{No}$ & $\begin{array}{c}\text { Nie wiem/l don't } \\
\text { know }\end{array}$ & $\chi^{2}$ & $\mathrm{df}$ & $\mathrm{p}$ \\
\hline \multirow[t]{2}{*}{ Płeć/Sex } & Kobieta/Woman & $83,1 \%$ & $1,7 \%$ & $15,3 \%$ & 18,21 & 6 & $0,01^{*}$ \\
\hline & Mężczyzna/Man & $68,9 \%$ & $13,1 \%$ & $18,0 \%$ & & & \\
\hline \multirow[t]{5}{*}{ Wiek/Age } & Poniżej 30 lat/Below 30 years & $81,0 \%$ & $9,5 \%$ & $9,5 \%$ & 9,04 & 12 & 0,70 \\
\hline & 30-39 lat/years & $76,0 \%$ & $4,0 \%$ & $20,0 \%$ & & & \\
\hline & 40-49 lat/years & $66,7 \%$ & $3,7 \%$ & $29,6 \%$ & & & \\
\hline & 50-59 lat/years & $77,8 \%$ & $11,1 \%$ & $11,1 \%$ & & & \\
\hline & 60 lat i powyżej/60 years and more & $79,3 \%$ & $10,3 \%$ & $10,3 \%$ & & & \\
\hline \multirow[t]{5}{*}{ Wykształcenie/Education } & Podstawowe/Primary & $66,7 \%$ & $11,1 \%$ & $22,2 \%$ & 9,74 & 15 & 0,84 \\
\hline & Gimnazjalne/Lower secondary & $100,0 \%$ & $0,0 \%$ & $0,0 \%$ & & & \\
\hline & Zasadnicze zawodowe/Vocational & $77,1 \%$ & $5,7 \%$ & $17,1 \%$ & & & \\
\hline & Średnie/Secondary & $82,9 \%$ & $4,9 \%$ & $12,2 \%$ & & & \\
\hline & Wyższe/Tertiary & $66,7 \%$ & $12,1 \%$ & $21,2 \%$ & & & \\
\hline \multirow{3}{*}{$\begin{array}{l}\text { Czas od } \\
\text { diagnozy/The time from a dia- } \\
\text { gnosis }\end{array}$} & Mniej niż rok/Less than one year & $64,0 \%$ & $12,0 \%$ & $24,0 \%$ & 18,41 & 9 & $0,03^{*}$ \\
\hline & 5 lat lub mniej/5 years or less & $70,2 \%$ & $8,5 \%$ & $21,3 \%$ & & & \\
\hline & Więcej niż 5 lat/More than 5 years & $87,5 \%$ & $4,2 \%$ & $8,3 \%$ & & & \\
\hline Czas od & Mniej niż rok/Less than one year & $63,8 \%$ & $19,2 \%$ & $16,9 \%$ & 9,28 & 9 & 0,41 \\
\hline \multirow[t]{2}{*}{$\begin{array}{l}\text { przeszczepienia/The time from } \\
\text { kidney transplantation }\end{array}$} & 5 lat lub mniej/ 5 years or less & $70,6 \%$ & $5,9 \%$ & $23,5 \%$ & & & \\
\hline & Więcej niż 5 lat/More than 5 years & $90,5 \%$ & $4,8 \%$ & $4,8 \%$ & & & \\
\hline
\end{tabular}

$\chi^{2}$ - test chi-kwadrat/chi-square test; df - liczba stopni swobody/degrees of freedom; p - poziom istotności/level of significance " $p<0,01 ; " p<0,05$

Źródło: opracowanie własne

Source: author's own analysis

\section{Dyskusja}

Przeszczepienie nerki, podobnie jak każdy poważny zabieg chirurgiczny, wywołuje u pacjenta szereg emocji, zarówno pozytywnych, jak i negatywnych. W procesie terapii pacjentów po transplantacji nerki bardzo ważną rolę odgrywa relacja pacjenta z personelem pielęgniarskim, która pozwala choremu zaadaptować się do nowej sytuacji życiowej [16, 17].

Badania przeprowadzone przez zespół Grochans [13] w oddziale chirurgii dotyczyły udzielania wsparcia emocjonalnego jako wyznacznika opieki pielęgniarskiej. W badaniu tym stwierdzono, że informacje na temat sposobu zachowania się po operacji uzyskało $84 \%$ respondentów, natomiast $49 \%$ ankietowanych zostało zapoznanych z regulaminem obowiązującym w oddziale. Wyniki badań własnych pokazały, że zdecydowana większość pacjentów uznała, iż przekazywane przez pielęgniarki informacje dotyczące zasad i zachowań obowiązujących w oddziale były udzielane na poziomie bardzo dobrym i dobrym. Informacje uzyskane od personelu pielęgniarskiego miały również pozytywny wpływ na poziom wiedzy pacjentów w zakresie zachowań związanych z chorobą i/lub przeszczepem. Odmienne wyniki uzyskali w swoich badaniach Surmacka i Motyka [18]: głównym problemem komunikacyjnym jest brak udzielania informacji przez personel pielęgniarski. Według tych badaczy personel skupia się jedynie na sferze fizycznej, z pominięciem sfery psychicznej pacjentów, zwłaszcza lekceważąc lęki i obawy dotyczące stanu zdrowia i hospitalizacji.

W badaniach Kamińskiej i wsp. [19] stwierdzono, że rozmowa z personelem pielęgniarskim miała znaczenie i wywierała wpływ na poczucie bezpieczeństwa w trakcie hospitalizacji. Zależność taka wystąpiła aż u około 80\% chorych. Zwłaszcza informacje na temat zakresu wykonywanych zabiegów pielęgnacyjnych i badań zwiększały poczucie bezpieczeństwa pacjentów. Przeprowadzone badania własne potwierdziły wpływ wsparcia informacyjnego na ten obszar funkcjonowania chorych.

Badania przeprowadzone przez zespół Bojanowskiej [7] wykazały, że 50\% ankietowanych nie było zadowolonych z jakości otrzymanych informacji na tematprocedur medycznych. Badacze podkreślają znaczenie komunikacji na płaszczyźnie pacjent - pielęgniarka: fakt bliskich kontaktów i częstych styczności, a w związku 
z tym uczestniczenia pielęgniarki w rozwiązywaniu problemów chorego. W badaniach własnych uzyskano rozbieżne wyniki. Informacje na temat zachowań i zasad obowiązujących w oddziale aż $82,5 \%$ badanych uznało za bardzo dobre i dobre. Większość, tj. 81,7\%, chorych potwierdziło również wpływ informacji udzielanych przez pielęgniarki na ich poziom wiedzy o chorobie i przeszczepie.

Zespół Pietrzak [15] opisuje rolę komunikacji z pacjentem, podkreślając, że skuteczna komunikacja terapeutyczna łagodzi negatywne emocje, takie jak przygnębienie i złość, oraz wpływa na poprawę samopoczucia pacjenta, wspiera go i pozwala nawiązać efektywną współpracę. Badania własne pokazały, że większość ankietowanych bardzo dobrze oceniło sposób udzielania informacji przez pielęgniarki oraz odczuwało pozytywny wpływ komunikacji z pielęgniarką na poprawę samopoczucia i obniżenie odczuwanego lęku. Natomiast udzielane wsparcie informacyjne pozwala na poprawę poczucia bezpieczeństwa. Wyniki te potwierdzają badania Grochans i wsp. [13], w których 96\% badanych potwierdzito znaczenie dobrego komunikowania się z personelem pielęgniarskim w trakcie hospitalizacji.

Radecka wraz z zespołem [20] podkreśla, że realizacja holistycznego modelu opieki nad chorym wymaga od personelu pielęgniarskiego wysokich kompetencji zawodowych, włącznie ze znajomością zasad komunikacji interpersonalnej. Autorzy uważają, że nie jest możliwe pielęgnowanie pacjenta bez uprzedniego nawiązania z nim kontaktu. Podkreślają również bardzo ważną rolę pielęgniarki nie tylko jako rozmówcy, ale również jako aktywnego słuchacza. Przypominają o znaczeniu rozmowy terapeutycznej z pacjentem, dzięki której ma on odzyskać poczucie bezpieczeństwa. Wyniki badań własnych potwierdzają doniesienia autorów o ważności i znaczeniu relacji terapeutycznej w łagodzeniu niepokoju, lęku i budowaniu poczucia bezpieczeństwa.

Rørtveit i wsp. [21], dokonując przeglądu literatury dotyczącego zaufania pacjentów do pielęgniarek w kontekście doświadczeń chorych, wskazali na kluczową rolę, jaką odgrywa nawiązanie relacji terapeutycznej. Autorzy wskazują na konieczność informowania pacjenta, co prowadzi do wcześniejszego wykrywania niepokojących objawów i daje choremu poczucie kontroli nad leczeniem. Zadowalające zatem wydają się wyniki badań własnych, w których informacje udzielane przez pielęgniarki zostały przez pacjentów ocenione, w zdecydowanej większości, jako dobre i bardzo dobre.

Gilbert [22] podkreśla rolę i znaczenie relacji terapeutycznej pielęgniarka - pacjent w udzielaniu informacji dotyczących kwestii zarówno medycznych, jak i psychospołecznych. Morow i Conner-Garcia [23] uważają natomiast, że relacja terapeutyczna ma bardzo istotne znaczenie w zrozumiałym przekazywaniu pacjentowi informacji, zarówno organizacyjnych, jak i dotyczących leczenia. Przeprowadzone badania własne pokazały, że informacje udzielane przez pielęgniarki pozytywnie wpłynęły na poziom wiedzy związanej z chorobą u zdecydowanej większości ankietowanych.

\section{Wnioski}

1. Badana grupa pacjentów wysoko oceniała znaczenie relacji terapeutycznej z personelem pielęgniarskim.

2. Wiek, płeć, wykształcenie, a także czas, który upłynął od przeszczepienia nerki i zdiagnozowania choroby, wpływały na poziom zadowolenia z relacji terapeutycznej z personelem pielęgniarskim.

3. Wsparcie informacyjne personelu pielęgniarskiego wywiera istotny wpływ na poczucie bezpieczeństwa i obniżenie lęku pacjentów po transplantacji nerki w trakcie hospitalizacji.

\section{Piśmiennictwo}

1. Myśliwiec M. Nefrologia. Warszawa: Medical Tribune Polska; 2017. 358-360.

2. Barański AG. Przeszczepianie nerek. Warszawa: PZWL; 2017. 24-25.

3. Myśliwiec M. Przewlekła choroba nerek. W: Szczeklik A. (red.). Interna Szczeklika. Kraków: Medycyna Praktyczna; 2012. 1407-1416.

4. Durlik M, Pączek L. Przeszczepianie nerek. W Myśliwiec M. (red.). Choroby nerek. Warszawa: PZWL; 2008. 562-593.

5. Rutkowski B, Król E. Epidemiology of chronic kidney disease in central and eastern Europe Blood Purif. 2008; 26(4): 381-385.

6. Bojanowska M, Hreńczuk M, Jonas M, Małkowski P. Leczenie hemodializami a przeszczepienie nerki w opinii pacjentów oczekujących na transplantację. Pielęg Pol. 2015; 3(57): 278-282.

7. Bojanowska M, Hreńczuk M, Sowińska R, Jonas M, Małtosz B, Małkowski P. Wiedza na temat przeszczepienia nerki u pacjentów oczekujących na transplantację. Probl Pielęg. 2014; 22(4): 420-425.

8. Serwańska-Świątek M, Gozdowska J, Dęborka-Materkowska D, Zygier D. Podstawy leczenia immunosupresyjnego po przeszczepieniu nerki. Terapia 2016; 24(1): 47-52.

9. Wilczek-Rużyczka E. Empathy in the therapeutic relationship between the physician, nurse and patient. New Medicine. 2009; 1: 24-28.

10. Kosowicz M. Poprawna komunikacja drogą do porozumienia. Prz Urol. 2012; 2: 24-30.

11. Jaracz J. Zaburzenia psychiczne i choroby nerek. Psychiatr Dypl. 2010; 7(5): 54-57.

12. Sieradzki A, Górska K. Objawy lękowe i depresyjne a poziom funkcjonowania w grupie osób po przeszczepie nerek i wątroby. Piel Zdr Publ. 2015; 5(3): 239-246.

13. Grochans E, Wieder-Huszla S, Jurczak A, Stanisławska M, Janic E, Szych Z. Wsparcie emocjonalne jako wyznacznik jakości opieki pielęgniarskiej. Probl Hig Epidemiol. 2009; 90(2): 236-239. 
14. Syguła K. Błędy w komunikacji. Mag Pielęg Położ. 2012; 7-8: 10-11.

15. Pietrzak A, Ograczyk A, Zalewska-Janowska A. Rola skutecznej i empatycznej komunikacji w podnoszeniu jakości życia pacjenta. Lek Wojsk. 2016; 4: 419-424.

16. Pluta A, Sulikowska B, Budnik-Szymoniuk M, Basińska-Drozd H. Udział pielęgniarki w opiece nad pacjentem po przeszczepieniu nerki. Journal of Education, Health and Sport. 2017; 7(7): 39-47.

17. Wiśniewska L, Paczkowska B, Białobrzeska B. Zapotrzebowanie na wsparcie emocjonalne wśród pacjentów leczonych nerkozastępczo. Forum Nefrol. 2010; 3(1): 63-70.

18. Surmacka J, Motyka M. Problemy w komunikacji klinicznej z pacjentem hospitalizowanym. Probl Pielęg. 2015; 23(3): 386-391.

19. Kamińska M, Brodowski J, Bażydło M, Dąbrowska O. Postawy personelu medycznego a poczucie bezpieczeństwa pacjenta. Fam Med Primary Care Rev. 2009; 11(4): 881-885.

20. Radecka I, Łopacińska I, Kopański Z, Brukwicka I, Lishchynskyy Y, Rowiński J. Znaczenie komunikacji interpersonalnej w pielęgniarstwie. JCHC. 2014; 4: 6-9.

21. Rørtveit K, Sætre B, Leikner I, Joa I, Testad I, Severinsson E. Patients' Experiences of Trust in the Patient - Nurse Relationship - A Systematic Review of Qualitative Studies. OJN. 2015; 5: 195-209.
22. Gilbert DA, Hayes E. Communication and outcomes of visits between older patients and nurse practicioners. Nurs Res. 2009; 58(4): 283-293.

23. Morrow DG, Conner-Garcia T. Improving comprehension of medication information: implications for nurse - patient communication. J Gerontol Nurs. 2013; 39(4): 22-29.

Artykuł przyjęty do redakcji: 12.03.2019.

Artykuł przyjęty do publikacj: 21.05.2019.

Źródło finansowania: Praca nie jest finansowana z żadnego źródła. Konflikt interesów: Autorzy deklarują brak konfliktu interesów.

Adres do korespondencji:

Joanna Owsianowska

ul. Żołnierska 48 budynek 8

Szczecin

tel. 914800910

e-mail: jowsian@pum.edu.pl

Zakład Pielegniarstwa Specjalistycznego, Wydział Nauk o Zdrowiu, Pomorski Uniwersytet Medyczny w Szczecinie 